\title{
Simple Purification of Vetiver Oil by Multiglass Plate System for Quality Improvement
}

\author{
Evi Yanto ${ }^{1}$, Egi Agustian ${ }^{2, *}$ and Anny Sulaswatty ${ }^{2}$ \\ ${ }^{1}$ Bogor Agriculture University, Kampus IPB Darmaga Bogor 16680 West Java, Indonesia \\ ${ }^{2}$ Research Centre for Chemistry-LIPI, Kawasan PUSPIPTEK Serpong, Tangerang Selatan 15314 Banten, \\ Indonesia \\ "Corresponding author : egiagustian@ gmail.com
}

\begin{tabular}{|c|c|}
\hline$A R T I C L E \quad I N F O$ & \multirow{9}{*}{$\begin{array}{l}\text { Abstract } \\
\text { Vetiver oil is one of essential oils from Indonesia with no synthetic } \\
\text { substitute available. The drawback of vetiver oil from Indonesia is smoky } \\
\text { odor and dark appearance. To increase added value of Indonesian vetiver } \\
\text { oil, method employing cheap production and simple operation is needed. } \\
\text { Multiglass plate system (MGS) is a method to increase added value of } \\
\text { vetiver oil. The aim of this research is to improve the quality of vetiver oil } \\
\text { produced by MGS method, in terms of appearance, odor and } \\
\text { physicochemical properties and also to optimize the operation condition } \\
\text { on the vetiver oil yield and total vetiverol contents. The process parameters } \\
\text { varied in this research are flow rate, angle and amount of glass plates. As } \\
\text { a result, optimum condition was obtained at flow rate of } 0.38 \text { ml/sec, glass } \\
\text { plate angular of } 3^{\circ} \text { and } 5 \text { glass plates to increase } 15 \% \text { of total vetiverol } \\
\text { contents, while the yields decreased up to 5.6\%. Refined vetiver oil by } \\
\text { MGS almost met the criteria ofIndonesia National Standard number 06- } \\
2386-2006 \text {, except for total vetiverol contents and odor. However, the total } \\
\text { vetiverol content increased and the odor became slightly smoky compare } \\
\text { to the raw material. Based on the results, MGS method can give higher } \\
\text { purification of vetiverol to increase vetiver oil quality with easy handling, } \\
\text { low cost operation and also portability. } \\
\text { C } 2016 \text { Indonesian Journal of Applied Chemistry. This is an open access }\end{array}$} \\
\hline Article history & \\
\hline Received date : 1 December 2016 & \\
\hline Revised date : 19 December 2016 & \\
\hline Accepted date : 30 December 2016 & \\
\hline $\begin{array}{l}\text { Available online at } \\
\text { http://kimia.lipi.go.id/inajac/index.php }\end{array}$ & \\
\hline Keywords: & \\
\hline & \\
\hline & \\
\hline
\end{tabular}

\section{INTRODUCTION}

Vetiver oil is obtained from roots of vetiver grass (Vetiveria Zizanoides (L) Nash) by steam distillation and hydrodistillation. This root iswidely found in tropical regions of Asia, Africa, Ocenia and Central America [1]. Indonesia, China and Haiti are major producers. About 60 to 75 tons of vetiver oil are annually produced from Indonesia and Indonesia becomes the major supplier of vetiver oil in the world [2]. Vetiver oil is traditionally known as vetiver oil in trade. It is also known as "oil of tranquality" and has a distinct fragrance with no synthetic substitute available [3]. Vetiver is one of the most important raw materials in perfumery both as a fixative and in its own right as fragrance ingredient [4]. Recent research has found new biological activities of vetiver oil and its components such as antifungal, antibacterial [5], anticancer [6], anti-inflammatory [7] and antioxidant activities [8]. These reasons made vetiver oil a promising candidate for application in the pharmaceutical industry. Chemical composition of vetiver oil is extremely complex. It mainly comprises of sesquiterpenes and sesquiterpene derivatives, of which vetiverols, their carbonyl compounds and esters are the main constituents. Their relative abundance normally establishes the oil quality [4,9].

Generally, vetiver oil from conventional distillation have several disadvantages on specification such as having dark color, containing impurities, and having burnt smell [10], because of poor distillation operation. Oil color greatly affects the quality, application and price [11]. 
Our research group used another method to improve the quality of vetiver oil, which is aging accompanied with stirring. The aging process has decreased smoky smell while other parameters for instance density and viscosity increase. Although, this process has very low cost, but it has several disadvantages such as long processing time (2-3 months), still dark brown color and also decreased yield.

Several researchers used another advanced method to improve the added value of vetiver oil. Andhika and Agustian et al, used the fractionation vacuum to increase the total vetiverol content from vetiver oil [12,13]; Sulaswatty and Agustian studied the extraction of vetiver oil using supercritical $\mathrm{CO}_{2}$ [14]; Danh et al explored the supercritical $\mathrm{CO}_{2}$ extraction of vetiver roots to decrease heavy metal in oil [15]. Maulana, et al., have obtained high quality vetiver oil by microwave steam distillation [16]. Putrawan and Eric used simple vacuum distillation of vetiver oil to increase the vetiverol contents until the required minimum contents of $50 \%$ was achieved [2].

According to those researchers, the vetiver oil increases the yield and quality of oil. However, the drawback of these method is the operation is very expensive and handling system is difficult [17]. In this ways to increasing the valorization of Indonesian vetiver oil.

The multiplate glass system (MGS) or papan bertingkat is one of new simple purification method to increase quality of vetiver oil with simple andeasy operation, mobile system and low cost. There are no reference about this system to decribe this method. This method was founded by some smallholders to upgrade the quality of vetiver oil. MGS has several glass plates that are connected to each other at certain angle to allow direct flow. Purification in the MGS is the evaporation of the unwanted components in the oil in order to eliminate the burning smell or smoky. Removing the heavy metals as complex ions in oil occurr in the MGS method due to the reaction of complex ions with air on the glass. However, the application of the MGS method to optimize operational condition on vetiver oil yield and chemical composition, has not previously been reported in the literature. The objective of the research is to improve quality of vetiver oil in terms of appearance, odor and physicochemical properties using MGS and also to optimize the operation condition on the vetiver oil yield and total vetiverol contents.

\section{EXPERIMENTAL}

\subsection{Materials}

Vetiver oil was obtained from local producer in Bayongbong, Garut, West Java, Indonesia. Specification of the vetiver oil was shown in Table 2. Chemical for instance ethanol p.a, $\mathrm{KOH}, \mathrm{HCl}, \mathrm{Na}_{2} \mathrm{SO}_{4}$ and phenolphthalein indicator were obtained from E-Merck.

\subsection{Methods}

The main equipment was Multiplate Glass System (MGS) that was designed and constructed by our group. MGS has dimension of $43 \times 40 \times 23 \mathrm{~cm}$, stainless steel 304 material and five glass plates. It was equipped with glass column of 1" diameter, glass funnel of 4" diameter and etc. Other tools for analysis are picnometer, polarimeter, refractometer, analytical balance etc. The schematic diagram of the MGS equipment used in this experiment is seen in Fig. 1.

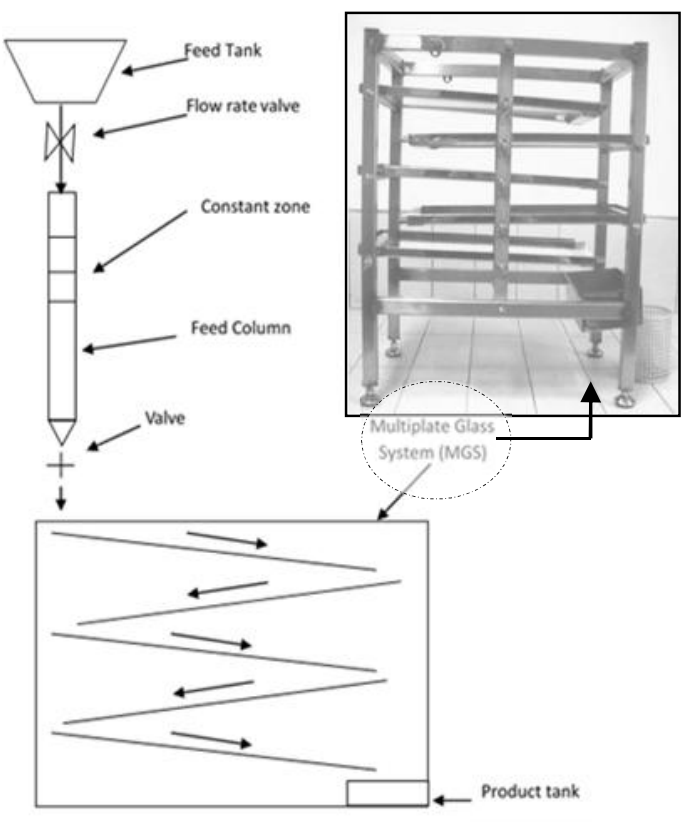

Fig. 1. Schematic equipment of multiglass plate system 
The first step in this research was calibrating the flow rate until fixed flow rate at $3^{\circ}$ of glass plate angle was founded. Based on the aging method for vetiver oil, the oil added to feed tank was around 55-69 ml, depending on the flow rate and plate angle.

The second step is conducting the main experiment. The flow rate was adjusted to 0.38 $\mathrm{ml} / \mathrm{min}$ (valve was fully open) or $0.22 \mathrm{ml} / \mathrm{min}$ (half open) and stopwatch was set. After oil filled the feed column, the oil then passed through to MGS equipment. The flow rate had to be constant, with height of the oil in the column feed was maintained into constant zone. The plate angleused three variations $\left(1.5^{0} ; 3^{0} ; 4.5^{0}\right)$ and the numbers of plates used was 1-5. The product was collected continuously in the storage tank and analyzed in the term of physical and chemical properties. All experiment was duplicated.

Design of experiment used completely randomized design of factorial by Microsoft excel. That method was applied in this study to evaluate the effect of flow rate, glass plate angle and amount of glass plates on the vetiver oil yield and total vetiverol contents. The experiment was planned using $3^{3}$ factorial design. For three parameters and three levels factorial set up the total number of experimental runs conducted were 22 experiments.

The total vetiverol contents in vetiver oil before and after purification were calculated from mean of ester value after acetylation $\left(\mathrm{E}_{2}\right)$ and mean of ester value before acetylation $\left(E_{1}\right)$ by the following equation (1) [18]:

$$
T \quad V \epsilon \quad(\%)=\frac{M\left(E_{2}-E_{1}\right)}{5-0.4\left(E_{2}\right)}
$$

Where,

$\mathrm{M}$ is molecular weight of vetiver oil.

\subsection{Product characterization}

Product samples were analyzed for odor, appearance, density, refractive index, solubility in ethanol, acid value, ester value before acetylation and ester value after acetylation based on method stated in Indonesia NationalStandard about vetiver oil [18]. The identification of chemical compositions of the purified oil was obtained by gas chromatography mass spectroscopy (GCMS), type QP 5000 Shimadzu, equipped with column DB $17(30 \mathrm{~cm}$ $\mathrm{x} 0.25 \mathrm{~mm})$. The oven temperature was programmed from $35^{\circ} \mathrm{C}(5 \mathrm{~min})$ to $250^{\circ} \mathrm{C}(45$ $\mathrm{min}$ ) at $5^{\circ} \mathrm{C} / \mathrm{min}$, with helium as carrier gas. The injector temperature of $150^{\circ} \mathrm{C}$, interface temperature of $250^{\circ} \mathrm{C}$, flow gas $14.8 \mathrm{ml} / \mathrm{min}$, split ratio 12 , and linier velocity of 36.3 .

\section{RESULT AND DISCUSSION \\ 3.1 Effect of flow rate of vetiver oil on the total vetiverol contents}

Flow rate of vetiver oil is a very important factor in the MGS to increase the total vetiverol contents. The effect of flow rate of vetiver oil at $3^{\circ}$ angle of glass plate on total vetiverol contents and yields are shown in Fig.2. Purification of vetiver oil by MGS at flow rate of $0.22 \mathrm{ml} / \mathrm{sec}$ and $0.38 \mathrm{ml} / \mathrm{sec}$ gave total vetiverol of $41.80 \%$ and $42.12 \%$, respectively. Total vetiverol contents did not differ significantly with flow rate variation. Meanwhile, the yields at flow rate of $0.38 \mathrm{ml} / \mathrm{sec}$ is $70.83 \%$ wt. It increased with increasingflow rate, compared to that at flow rate of $0.22 \mathrm{ml} / \mathrm{sec}(63.78 \% \mathrm{wt})$.

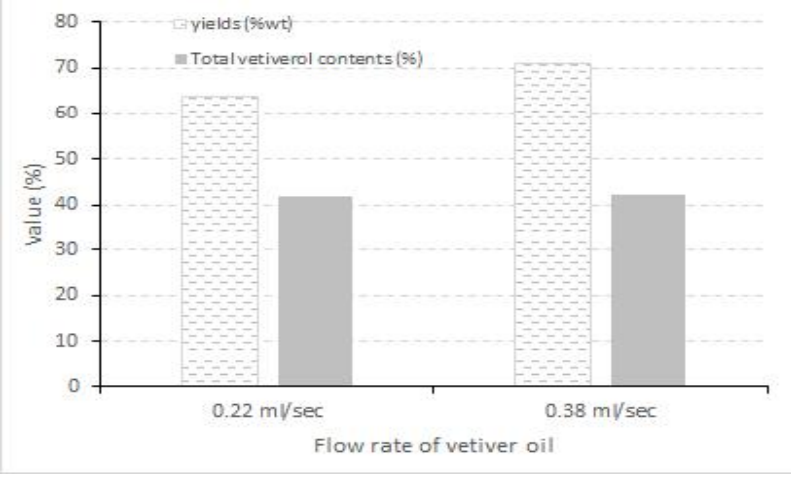

Fig. 2. Effect of flow rate of vetiver oil on the yields and total vetiverol contents at $3^{\circ}$ of glass plate angular.

The increase of yield at $0.38 \mathrm{ml} / \mathrm{sec}$ was influenced by the angleof glass plates and driving force of oil with gravity force. Fig. 2, indicated that the angle of glass plates at $3^{\circ}$ induced greater resulting forces due to the influence of gravity and the greater the angle. The higher driving force resulted in oil entrained in the glass plate so that the less oil yield 
increases. The driving force is the product of mass and acceleration. The greater flow rate resulting in greater force so that larger amount of oil entrained in the plates due to less friction so that the yield increases.

The vetiver oil after purification by MGS was compared to vetiver oil as raw material. The purifiedproducts were better than the raw material in terms of odor (Table 1). According to Rahayu, panel test of odor followed this method [19]. The results of the odor test showed that the average value of ratings that panelists provided was positive number that indicated the smell of vetiver oil was be better than the raw material. Decreased of smoky smell was shown at 0.22 $\mathrm{ml} / \mathrm{sec}$ with odor value of 1.75 , compared to vetiver oil before purification of 0.82 . Most of the compounds forming the smoky smell suffered due to evaporation of oil movement during the past MGS. The smoky compound comprised mostly of sesquiterpenic derivates including hydrocarbons, alcohol aldehydes, organic acids and ketones [3,20].

Table 1. Odor value of vetiver oil by MGS method

\begin{tabular}{ccc}
\hline $\begin{array}{c}\text { Flow rate of } \\
\text { vetiver oil }\end{array}$ & $\begin{array}{c}\text { Glass plate angular } \\
\text { (degree angle) }\end{array}$ & $\begin{array}{c}\text { Average Odor } \\
\text { Value }\end{array}$ \\
\hline $\begin{array}{c}\text { Vetiver oil as } \\
\text { raw material }\end{array}$ & - & 0.82 \\
\hline $0.22 \mathrm{cc} / \mathrm{sec}$ & 1.5 & 1.75 \\
\cline { 2 - 3 }$($ Half Open $)$ & 3 & 1.33 \\
\cline { 2 - 3 } & 4.5 & 1.42 \\
\hline $0.38 \mathrm{cc} / \mathrm{sec}$ & 1.5 & 1.67 \\
\cline { 2 - 3 }$($ Fully Open $)$ & 3 & 1.53 \\
\cline { 2 - 3 } & 4.5 & 1.33 \\
\hline
\end{tabular}

\subsection{Effect of glass plate angle on the total vetiverol contents}

Fig. 3. shows the effect of glass plate angle on the total vetiverol contents and yields. The results of MGS method gave the highest total vetiverol of $42.12 \%$ at $3^{\circ}$ of glass plate angle and low total vetiverol is $39.72 \%$ at $45^{\circ}$ glass plate angle. But, there are different phenomenon for yields. In the Fig 3, the yields of vetiver oil has the increasing trend with increasing the glass plate angle. The $1.5^{\circ}$ of glass plate angle obtained lower contents and increase at $3^{\circ}$ until $4.5^{\circ}$ of glass plate angular. The higher yields about $78.32 \% \mathrm{wt}$ is shown at $4.5^{\circ}$ of angle,indicated that the impurities in the vetiver oil is not separated on the glass plate due to flow rate of vetiver oil is of rapid velocity. It's clearly evidentthat the total vetiverol at $4.5^{\circ}$ of angle was not significantly different with that of vetiver oil as raw material.

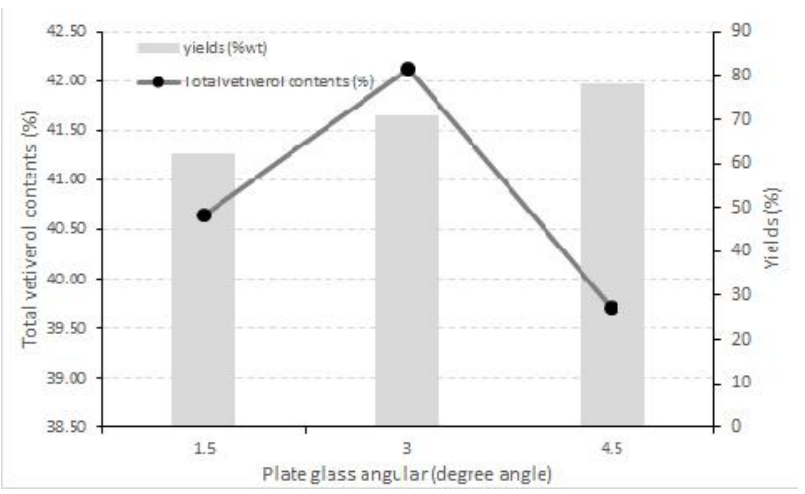

Fig. 3. Effect of glass plate angleon the yields and total vetiverol contents at $0.38 \mathrm{ml} / \mathrm{sec}$ of flow rate.

It seems that the Fig 3 shows the optimum glass plate angleis $3^{\circ}$. According to Putrawan, the vetiverol content appeared to correlate with density [2]. In this case, high density at $3^{\circ}$ of glass plate angle was obtained to increase the total vetiverol in vetiver oil as shown in Table 2. Purification in the glass plate occurred because the volatile compound was evaporated in room temperature. Besides, the odor was of different taste with presence of glass plate at $3^{\circ}$ angleand the volatile impuritycompounds were retained inside of oil layer on the glass plate. This influenced the odor of vetiver oil but the specific characteristic compounds in vetiver oil did not change.

\subsection{Effect of amount of glass plates on the total vetiverol contents}

Fig. 4. showed that the amount of glass plates on the total vetiverol contents, yields and process loss with fixed flow rate of vetiver oil and glass plate angle of $3^{\circ}$. Increasing amount of glass plates is obtained with decrease in the yield and increase in the total vetiverol contents. The purification has occurred at 5 glass plates. It was observed that the total vetiverol was $41.48 \%$. The trend curve was very interesting that at 1 plate it had $39.99 \%$ of vetiverol contents and it decreased at 3 plate (about $38.77 \%$ of vetiverol contents). It was the same trend at 4 plate until 5 
plate it increased. It seem that the purification occurred due to the movement of vetiver oil that passed on glass plate and resulted in impurities components being evaporated. Density has increased concurrently with the decrease in the amount glass plate that was displayedin Table 2 . The total vetiverol increased but the yield decreased as amount of glass plates were varied. This phenomenon occurred because undesired component such as terpenes groups with low boiling point evaporated at room temperature and caused total vetiverol increase.

There was no significant different on the process loss with correlation of amount of glass plates. The process losses with amount of glass plate were between $5.18-6.39 \%$ wt. The result was due to the oil on the glass plate that had very high viscosity and adhered on the glass plate. It was very difficult to collect that.

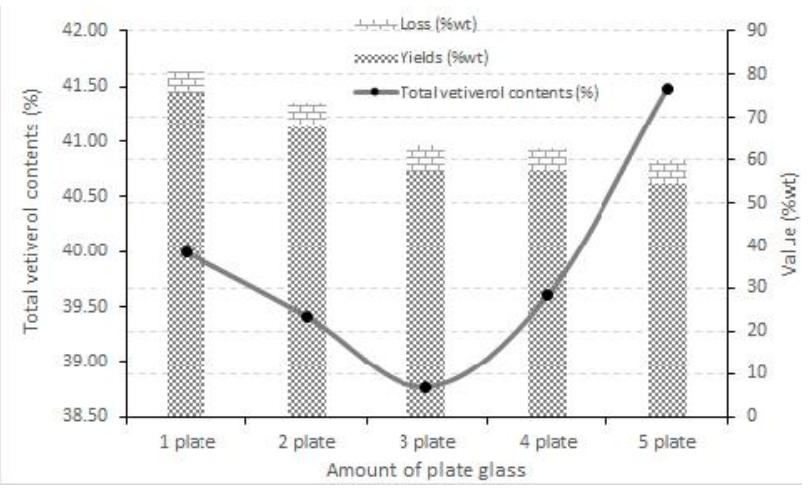

Fig. 4. Effect of amount of plate glass on the yields and total vetiverol contents and also lose process at $0.38 \mathrm{ml} / \mathrm{sec}$ of flow rate and $3^{\circ}$ of glass plate angular

\subsection{Physical and chemical properties of vetiver oil.}

The properties of vetiver oil after purification by MGS method are given in Table 2. As shown in the table, the total vetiverol contents were lower than the required standard. Moreover, they smelled slightly smoky and their color were reddish brown. But, based on parameter required, vetiver oil from MGS method fulfilled the standard, except for total vetiverol contents and odor. All samples were soluble in ethanol at 1:1 volume ratio. The contents of free fatty acid as acid value was lower compare to vetiver oil as raw material. This indicated that acid value compound in vetiver oil purified at the lighter fractions [2]. Moreover, the ester number before acetylation decreased compared to raw material because several ester compounds underwent direct oxidation and reduction to other compounds [3]. However, the ester number after acetylation increased compare to raw material. It seem that the ester after acetylation influenced vetiverol contents. The value of viscosity was higher than raw material and it clearly showed that higher density gave higher viscosity because the volatile compound or lighter fraction was separated on the glass plate.

Table 2. Chemical and properties of vetiver oil by MGS at $0.38 \mathrm{ml} / \mathrm{sec}$ of flow rate, $3^{\circ}$ of angular glass plate and 5 glass plate

\begin{tabular}{|c|c|c|c|}
\hline Parameter & $\begin{array}{c}\text { Vetiver } \\
\text { oil as } \\
\text { raw } \\
\text { material }\end{array}$ & $\begin{array}{l}\text { Vetiver } \\
\text { oil } \\
\text { purified }\end{array}$ & $\begin{array}{l}\text { Vetiver oil } \\
\text { Standar }\end{array}$ \\
\hline $\begin{array}{l}\text { Density at } \\
20^{\circ} \mathrm{C}(\mathrm{g} / \mathrm{ml})\end{array}$ & 1.0065 & 1.0097 & $\begin{array}{c}0.980 \text { to } \\
1.003 \\
\end{array}$ \\
\hline Viscosity (cp) & 551.62 & 942.6 & N.A \\
\hline Color & $\begin{array}{l}\text { Dark } \\
\text { reddish } \\
\text { brown }\end{array}$ & $\begin{array}{l}\text { reddish } \\
\text { brown }\end{array}$ & $\begin{array}{l}\text { pale yellow } \\
\text { to reddish } \\
\text { brown }\end{array}$ \\
\hline Odor & smoky & $\begin{array}{l}\text { slight } \\
\text { smoky }\end{array}$ & $\begin{array}{c}\text { vetiver } \\
\text { characteristic }\end{array}$ \\
\hline $\begin{array}{l}\text { Solubility in } \\
\text { ethanol } 95 \% \\
(1: 1)\end{array}$ & $\begin{array}{c}\text { Clear in } \\
1: 1 .\end{array}$ & $\begin{array}{c}\text { Clear in } \\
1: 1\end{array}$ & Clear in $1: 1$ \\
\hline $\begin{array}{l}\text { Optical } \\
\text { Rotation }\end{array}$ & +18.61 & +16.265 & N.A \\
\hline $\begin{array}{l}\text { Refractive } \\
\text { Index }\left(20^{\circ} \mathrm{C}\right)\end{array}$ & 1.5302 & 1.5308 & 1.52 to 1.53 \\
\hline $\begin{array}{l}\text { Acid number } \\
(\mathrm{mg} \mathrm{KOH} / \mathrm{g})\end{array}$ & 12.58 & 11.5 & 10 to 35 \\
\hline $\begin{array}{l}\text { Ester number } \\
\text { before } \\
\text { acetylation } \\
(\mathrm{mg} \mathrm{KOH} / \mathrm{g})\end{array}$ & 22.97 & 18.57 & 5 to 26 \\
\hline $\begin{array}{l}\text { Ester number } \\
\text { after } \\
\text { acetylation } \\
(\mathrm{mg} \mathrm{KOH} / \mathrm{g})\end{array}$ & 106.69 & 116.6 & 100 to 150 \\
\hline $\begin{array}{l}\text { Total } \\
\text { vetiverol }(\%)\end{array}$ & 35.68 & 42.12 & Min. $50 \%$ \\
\hline
\end{tabular}

The chromatogram of chemical compounds by GCMS is shown in Fig.5. It was seen that the increase and decrease of peak for every composition of vetiver oil before (A) and 
after purification by MGS method (B) is clearly different. The sesquiterpene hydrocarbon group is major compounds that had decreased content after MGS purification. It showed on the before peak number 1 . But, overall the peak of vetiver oil (A) had similar trend with that after purification (B). This evidence verified that the MGS method was successful to purify the vetiver oil without adding any chemicals.

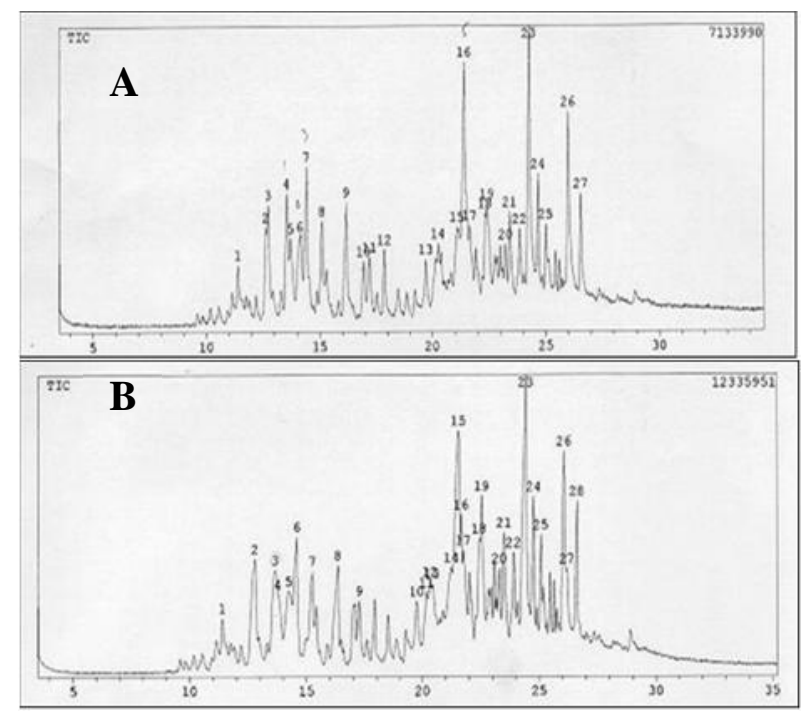

Fig. 5. Chromatogram of vetiver oil before $(A)$ and after purification by MGS method (B) ( $3^{\circ}$ of glass plate angular, $0.38 \mathrm{ml} / \mathrm{sec}, 5$ of amount of glass plate)

The compounds of vetiver oil as raw material were shown in Table 3 and they were similar to the profile of the vetiver oil by MGS method. The compounds of vetiver oil were analyzed by GCMS with the similarity index above $80 \%$. Overall results showed that compound by MGS system was higher than vetiver oil as raw material. The main constituents of vetiver oil comprised of sesquiterpene hydrocarbons such as alpha amorphene, alpha gurjunene, kuparen, alpha copaene, dehydroaromadendrene, caryphyllene oxide, and their alcohol derivatives- vetiverol such as tricyclo vetiverol, juniper champor, bicyclo, chusimol. Carbonyl derivatives-vetivones were for instance beta vetivone, alpha vetivone. Their compounds were the same result with Sellier et. al [21]. The results showed that content of all components increased or decreased depending on process parameters. This indicated that vetiver oil composition was quite complex. It consists of many components with a wide boiling point range [2]. More than 150 constituents have been identified in vetiver root oils produced in different countries [22]. However, many components are still unidentified. Table 3 showed that the major compound of vetiver oil after purification slightly increased compared to raw material, but the compound that significantly decreased was sesquiterpene hydrocarbons group. Such component were below $80 \%$ of similarity index, due to the compound coalesced into layer on the glass plate.

Table 3. Chemical composition of vetiver oil before and after purification by MGS method ( $3^{\circ}$ of glass plate angular, $0.38 \mathrm{ml} / \mathrm{sec}, 5$ of amount glass plate)

\begin{tabular}{|c|c|c|c|}
\hline \multirow[b]{2}{*}{ No } & \multirow[b]{2}{*}{ Compound } & \multicolumn{2}{|c|}{ Concentration (\%) } \\
\hline & & $\begin{array}{l}\text { Vetiver oil as } \\
\text { raw material }\end{array}$ & $\begin{array}{l}\text { Vetiver oil by } \\
\text { MGS method }\end{array}$ \\
\hline 1 & Similarity Index $<80$ & 7.47 & 2.04 \\
\hline 2 & Alpha - Amorphene & 3.89 & 6.55 \\
\hline 3 & Alpha - Gurjunene & 4.43 & 3.37 \\
\hline 4 & Kuparen & 4.43 & 4.34 \\
\hline 5 & $\alpha$-Copaene & 3.37 & 3.07 \\
\hline 6 & Dehydroaromadendrene & 3.67 & 3.77 \\
\hline 7 & (-)- Caryophyllene oxide & 11.08 & 9.94 \\
\hline 8 & Juniper Chompor & 3.27 & 3.05 \\
\hline 9 & Bisiklo Vetiverol & 6.34 & 4.2 \\
\hline 10 & Khusimol & 3.56 & 3.8 \\
\hline 11 & Not identified & 2.93 & 3.12 \\
\hline 12 & Trisiklo Vetiverol & 10.09 & 9.01 \\
\hline 13 & Vetiver Alkohol & 2.96 & 3.57 \\
\hline 14 & $\beta$ - Vetivone & 7.33 & 5.24 \\
\hline 15 & $\alpha$-Vetivone & 3.53 & 3.77 \\
\hline & Total & 78.35 & 68.84 \\
\hline
\end{tabular}

\section{CONCLUSION}

A simple purification of vetiver oil by Multiplate Glass System (MGS) has been used to improve the quality of vetiver oil. Refined Vetiver oil by MGS almost fulfilled Indonesia National Standard number 06-2386-2006 except for total vetiverol contents and odor. However, the total vetiverol content increased and the odor became slightly smoky compared to raw material.

The optimum process parameters used on MGS system increased up to $15 \%$ of total vetiverol contents. Nevertheless, yield 
decreased by $5.6 \%$ compared to vetiver oil content in raw material. The main compounds of vetiver oil and the characteristic of vetiver oil odor weres still the same with the raw material. Thus, this method approximately could increase added value of vetiver oil with easy-to-handle and low cost operation. It also can be moved to anywhere due to portable unit and mobile system.

\section{ACKNOWLEDGMENTS}

The authors are grateful to the Government of Indonesia for financial support for this project. Thanks to Dr. Meika Syahbana Rusli and Ir. Hasyim Asngari for their assistance and advice.

\section{REFERENCES}

[1] N. Dudai, E. Putievsky, D. Chaimovith, and M. Ben-Hur."Growth management of vetiver (Vetiveria zizanoides) under Meditterranea conditions". J. Environ. Manage., vol.81, pp. 63-71, 2006.

[2] Putrawan, I, D, G, A and Eric, F., "Simple vacuum distillation of vetiver oil from smallholders for quality improvement", Global Journal of Research in Engineering:C. vol 15(3), pp. 1-7, 2015.

[3] Chahal, K.K., Bhadwaj, U., Kaushal, S., and Sandhu, A.K. "Chemical compositio and biological properties of Chrysopogon zizanioides (L) Roberty syn. Vetiveria zizanioides (L) Nash-A Review", Indian Journal of Natural product and resources. vol. 6(4), pp. 251-260, 2015.

[4] U.C. Lavania, "Other uses and utilization of vetiver: vetiver oil". The Third International Vetiver Conference, Guangzhou, China, 2003.

[5] S.R. Sridhar, R.V. Rajagopal, R. Rajavel, S. Masilamani, and S.Narasimhan. "Antifungal activity of some oils". J. Agric. Food Chem. vol.51, pp.7596-7599, 2003.

[6] F. Chen, X. Wang, and H.J. Kim, "Antioxidant, anticarcinogenic and termiticidal activities of vetiver oil". Proceeding of Third International Vetiver Conference, Guangzhou, China, 2003.

[7] A.G. Jagtap, S.S. Shirke, and A.S. Phadke, "Effect of polyherbal formulation on experimental models of inflammatory bowel diseases", J. Ethnopharmacol, vol. 90, pp. 195-204, 2004.

[8] H. Kim, F. Chen, X. Wang, H.Y. Chung, and Z. Jin. "Evaluation of antioxidant activity of vetiver (Vetiveria zizanoides L.) oil and identification of its antioxidant constituents". J. Agric. Food Chem. vol.53, pp. 7691-7695, 2005.

[9] A. Kadarohman, Ratnaningsih Eko S, Gebi Dwiyanti, Lela Lailatul K, Ede Kadarusman, and Ahmad Nur F, "Quality and chemical composition of organic and non-organic vetiver oil". Indo. J. Chem, vol.14(1), pp. 4350, 2014.

[10] Ketaren, S. Prospek Pengembangan Minyak Atsiri Indonesia. Balai Besar Industri Hasil Pertanian, 1992.

[11] Hambali, Erliza dan Nina Rohayati. Teknologi Produksi Minyak Akar Wangi Skala Industri Kecil Pedesaan. Fateta-IPB, 1997.

[12] Adhika, Bayu. "Fraksionasi Minyak Akar Wangi dengan Teknik Packed Column Vacuum Distillation" thesis bachelor, Bogor Agriculture University, Indonesia, 2004.

[13] E. Agustian, A. Sulaswatty, Joddy. A.L, and Indri. B.A. "Peningkatan kadar vetiverol minyak akar wangi dengan cara distilasi vakum skala bench", Prosiding Indonesian Symposium On Science \& Technology on Chemistry, Serpong, 2006.

[14] Sulaswatty A. and E .Agustian. "Nilai tambah minyak akar wangi dengan peningkatan kadar vetiverol menggunakan ekstraksi $\mathrm{CO}_{2}$ fluida superkritik". Jurnal Kimia Terapan Indonesia, vol.16(2), pp. 7681, 2014.

[15] L. T. Danh, Paul Truong, Raffaella Mammucari, and Neil Foster. "Extraction of vetiver essential oil by ethanol-modified supercritical carbon oxide", Chemical Engineering Journal, vol. 165, pp. 26-34, 2010.

[16] Maulana, M. Al Hanif, Halim, Al Mushawwir, and Mahfud, "Ekstraksi minyak atsiri dari minyak akar wangi menggunakan metode steam hydro distillation dan hydro distillation dengan pemanas microwave", Jurnal Teknik Pomits, vol. 2(2), pp. 219-223, 2013

[17] Dianawati, Ermita. "Mempelajari proses pemurnian minyak akar wangi di sentra 
pp. 124-131, December 2016

industri kecil minyak akar wangi kabupaten Garut". Report of research industry, Bogor Agriculture University, Indonesia, 2001.

[18] National Standardization Agency of Indonesia (SNI) about Indonesia vetiver oil, No 06-386-2006.

[19] Rahayu, Winiati Pudji. Penuntun praktikum penilaian organoleptik. Bogor Agriculture University, Indonesia, 1998.

[20] Ketaren, S. Pengantar Teknologi Minyak Atsiri. Balai Pustaka, Jakarta, 1985.

[21] Sellier, N, Cazaussus, A., and Budzinski, H. "Structure determination of sesquiterpenes in Chinese vetiver oil by gas chromatographytandem mass spectrometry". J Chromatogr, vol.557, pp.454-458, 1991.

[22] Mallavarapu, G.R., Syamasundar, S,R., and Bhaskaruni, R.R.R. "Constituents of south Indian Vetiver oils". Natural Product Communications, vol.7(2), pp. 223-225, 2012. 